\title{
Long-Term Combined Effects of Crude Oil and Dispersant on Sediment Bacterial Community
}

\author{
Mohammed Al-Jawasim* \\ Department of Environmental Science/ University of Al-Qadisiyah, Al-Dewaniya, 58014, Iraq \\ Received: $16 / 08 / 2020$ \\ Accepted: 13/11/2020 \\ Published: 20/03/2021
}

\begin{abstract}
To better understand long-term combined effects of crude oil and dispersant on bacterial community, sediments microcosms were set up in triplicates and treated with dispersant (Corexit 9500A), crude oil, and Corexit 9500A plus crude oil. After 60 days exposure, there was a significant change in the bacterial community structure in all treatments. The shift in the bacterial community structure in Corexit 9500A plus crude oil treatment was considerably different from those by either Corexit 9500A or crude oil. DNA sequence analysis showed that Hydrocarboniphaga effuse, Parvibaculum lavamentivorans, and Alicyclobacillus ferrooxydans were the major bacterial species in crude oil treatment. Pandoraea thiooxydans, Janthinobacterium sp. and Hyphomicrobium nitrativorans were the most dominant species in Corexit 9500A treatment. The species Janthinobacterium sp., Parvibaculum lavamentivorans, and Dyella sp. were enriched in Corexit 9500A plus crude oil treatment. The majority of the detected species were hydrocarbons degraders. The study showed that Corexit 9500A addition enhanced the biodegradation rate by increasing the diversity and richness of hydrocarbons degrading species. Corexit A9500 application should be considered during crude oil spills to evaluate environmental impacts.
\end{abstract}

Keywords: Corexit A9500, crude oil, combined effects, bacterial community structure, hydrocarbons

\section{Introduction}

Crude oil is a complex mixture of various organic and inorganic compounds including hydrocarbons, resins, and asphaltenes. Crude oil is released into marine environments by natural and anthropogenic activities, which contribute up to $53 \%$ of entire oil spills [1]. Oil spills severely impact ecosystems and cause long-term environmental damages [2], ranging from molecular to organismal levels [3]. Bioremediation is a process that employs natural microorganisms to break down complex toxic compounds to less toxic or non-toxic compounds. Microorganism uses pollutants as sole sources of energy and consequently break them from toxic compounds to benign wastes that have no harmful effects on the environment. Due to its high selectivity and specificity of removing pollutants, cost efficiency, and less installing requirements, the bioremediation process is preferred over other physiochemical methods. Pollutants generally increase the microbial lag phase and therefore reduce the biodegradation rate [4]. Bioremediation is affected by a number of factors such as presence of appropriate biodegradingorganisms, the concentration of contaminants, and nutrients bioavailability temperature, oxygen, $\mathrm{pH}$, degree of acclimation, cellular transport properties and chemical structure of the compound [5]; therefore, bioremediation occurs on a relatively slow rate [6].

Dispersant application is one of the strategies that have been employed since the 1950s to mitigate oil spill impacts on aquatic environments [7]. Dispersants are mixtures of surfactants, solvents, and other compounds [8,9]. Dispersants break up oil slicks into micron-sized droplets by reducing the interfacial tension at oil-water interfaces $[9,10,11]$. The droplets spread in the water column inhibiting surface oil slicks formation. Breaking down oil slicks into tiny droplets increases oil bioavailability to indigenous oil degrading microbes and consequently increase crude oil biodegradation rate $[1,2]$. A study found the number of hydrocarbon-degrading microorganisms and the total carbon mineralization are being increased by the chemical dispersant Corexit 9500A [12]. Another study demonstrated that approximately $60 \%$ of crude oil was degraded after Corexit 9500A treatment [13]. It was found that the biodegradation rate of crude oil increased in response to Corexit 9500A addition [11]. The short exposure period (7 days) to crude oil and Corexit 9500A plus crude oil exert no impact on the bacterial community [14]. The objectives of this research are to examine the combined effects of Corexit 9500A plus crude oil after 60 days incubation and to identify the bacterial taxa that dominate the bacterial community under these conditions.

\section{Materials and Methods \\ 2.1 Study area}

The study area was a salt marsh at the eastern side of Lake Pontchartrain, Louisiana (N30 $08.782^{\prime}$ W89 $\left.9^{\circ} 44.665^{\prime}\right)$. The marsh was dominated by two marsh plants species Spartina patens and $S$. alterniflora. After removing the surface plants, the top $30 \mathrm{~cm}$ of sediments was collected. The sample was kept in sterilized polyethylene containers, sent on ice to the Troy University/Department of Biological and Environmental Science's laboratory, and stored at $4^{\circ} \mathrm{C}$ before analysis.

\subsection{Chemical analyses}

Chemical analyses were performed to evaluate the factors that might influence the bacterial community. The chemical analyses were done at the Central Analytical Instruments research Laboratory, Louisiana State University (Baton Rouge, LA). Metals, anions and total phosphorous were analyzed by

Corresponding author: Mohammed Al-Jawasim, Department of Environmental Science/ University of Al-Qadisiyah, Al-Dewaniya, 58014, Iraq; Tel: 009647832672007; E-mail: mohammedaljawasim@qu.edu.iq 
EPA methods 200.7, 300.0 and 365.3, respectively (Table 1). Table 1. Chemical characteristics of the salt marsh sediment addressing the factors that might affect the bacterial community.

\begin{tabular}{|c|c|}
\hline Factor & Value \\
\hline Aluminum (mg/kg) & ND* \\
\hline Antimony (mg/kg) & 0.1 \\
\hline Arsenic (mg/kg) & 6 \\
\hline Barium (mg/kg) & 12.7 \\
\hline Beryllium (mg/kg) & 0.7 \\
\hline Boron (mg/kg) & 28.8 \\
\hline Cadmium (mg/kg) & 0.9 \\
\hline Calcium (mg/kg) & 1058.4 \\
\hline Carbon (\%) & 7.202 \\
\hline Chloride (mg/L) & 7947.47 \\
\hline Chromium (mg/kg) & 17.5 \\
\hline Cobalt (mg/kg) & 5 \\
\hline Copper (mg/kg) & 117.7 \\
\hline Fluoride (mg/L) & 3.97 \\
\hline Iron $(\mathrm{mg} / \mathrm{kg})$ & 19913.5 \\
\hline Lead (mg/kg) & 37.2 \\
\hline Magnesium (mg/kg) & 5563 \\
\hline Manganese (mg/kg) & 123.6 \\
\hline Molybdenum (mg/kg) & ND \\
\hline Nickel (mg/kg) & 15.3 \\
\hline Nitrate (mg/L) & 11.38 \\
\hline Nitrite (mg/L) & 21.74 \\
\hline Nitrogen $(\%)$ & 0.433 \\
\hline $\mathrm{pH}$ & 7.06 \\
\hline Phosphate (mg/L) & 0.03 \\
\hline Phosphorus (mg/kg) & 605 \\
\hline Potassium (mg/kg) & 2364.8 \\
\hline Selenium (mg/kg) & ND \\
\hline Silicon (mg/kg) & 776.8 \\
\hline Sodium (mg/kg) & 808 \\
\hline Sulfate $(\mathrm{mg} / \mathrm{L})$ & 109.56 \\
\hline Sulfur (mg/kg) & 5304.7 \\
\hline Thallium (mg/kg) & ND \\
\hline $\operatorname{Tin}(\mathrm{mg} / \mathrm{kg})$ & 0.4 \\
\hline Vanadium (mg/kg) & 36.7 \\
\hline Yttrium (mg/kg) & 13 \\
\hline Zinc (mg/kg) & 84.5 \\
\hline
\end{tabular}

*ND: not detected

\subsection{Microcosms preparation and DNA extraction}

The crude oil Western Texas Intermediate (WTI) was purchased from Texas Raw Crude (Midland TX). The dispersant Corexit 9500A was provided by the Nalco Energy Services (Sugar Land TX). Four sets of microcosms, (1) untreated control, (2) treated with $0.2 \%(\mathrm{v} / \mathrm{w})$ Corexit 9500A, (3) treated with $2 \%(\mathrm{v} / \mathrm{w}) \mathrm{WTI}$, and (4) treated with $0.2 \%$ Corexit 9500A and 2\% WTI were prepared in triplicates. One gram of sediment was aseptically transferred into sterile $2 \mathrm{~mL}$ tubes, sealed with a Teflon-coated cap. Corexit 9500A and crude oil were added by a micropipette. The microcosms were incubated aerobically at $30{ }^{\circ} \mathrm{C}$. The microcosms were sampled after 60 days of incubation. By using the PowerSoil DNA Isolation Kit (MoBio Laboratories, Carlsbad, CA), total DNA was extracted from $0.3 \mathrm{gm}$ of sediments and stored at $-20{ }^{\circ} \mathrm{C}$ prior to analysis.

\subsection{Polymerase chain reaction (PCR)}

Nested PCR was implemented to amplify the total bacterial 16S rRNA gene. The primers $27 \mathrm{~F}$ and $1522 \mathrm{R}$ were used in the first round of the reaction. The final volume of the PCR mixture was $50 \mu \mathrm{L}$ containing $10 \mathrm{pmol}$ of $27 \mathrm{~F}$ and $1522 \mathrm{R}$ primers, $1 \mu \mathrm{L}$ of template DNA, $0.25 \mathrm{mM}$ of dNTP, $5 \mu \mathrm{L}$ of $10 \mathrm{x}$ Green Taq PCR buffer, and $1 \mathrm{U}$ of Green Taq DNA polymerase (GenScript, Piscataway, NJ). PCR was performed with a DNA thermal_cycler (GeneAmp PCR System 2700, Applied Biosystems, Foster City, CA) at an initial temperature of $94{ }^{\circ} \mathrm{C}$ for 5 minutes, followed by 30 cycles of $94^{\circ} \mathrm{C}$ for 20 seconds, $55{ }^{\circ} \mathrm{C}$ for 45 seconds, and $72{ }^{\circ} \mathrm{C}$ for 45 seconds. A final elongation step was carried out at $72{ }^{\circ} \mathrm{C}$ for 7 minutes. The primers $341 \mathrm{~F}$ and $534 \mathrm{R}$ were used in the second round of the reaction to amplify the $\mathrm{V} 3$ region of the $16 \mathrm{~S}$ rRNA gene [15]. About $1 \mu \mathrm{L}$ of the PCR products of the first round were used as a template for the second-PCR-round. PCR constituents and conditions were the same as described above. The resulting PCR products were confirmed by an agarose gel electrophoresis.

\subsection{Denaturing gradient gel electrophoresis (DGGE)}

PCR products of the second-round were separated on an $8 \%$ polyacrylamide gel with a $40-60 \%$ denaturing gradient of urea in 1.0x TAE buffer by a Bio-Rad DCodeTM Universal Mutation Detection System (Bio-Rad Laboratories, Hercules, CA). A stacking gel (a non-denaturing polyacrylamide gel) was prepared to make sample-loading wells on top of the denaturing-gradient gel. Forty five $\mu \mathrm{L}$ of PCR products were loaded into the wells. The electrophoresis process was conducted at $60^{\circ} \mathrm{C}$ at $40 \mathrm{~V}$ for 15 hours. After electrophoresis, the gels were stained with ethidium bromide for 15 minutes and photographed on a UV transilluminator (Fisher Scientific, Pittsburgh, PA).

\subsection{DNA sequencing}

Ten DGGE bands were excised from the gel and incubated separately overnight at $4^{\circ} \mathrm{C}$ with $50 \mu \mathrm{L}$ of distilled water to allow the DNAs to be released into the water. PCR was performed to re-amplify the eluted DNA. PCR constituents and conditions were the same as described in the first-round PCR except that the reaction was carried out for 35 cycles. The purity and position of the re-amplified DNAs were verified by conducting the DGGE analysis. If necessary, the DGGE bands were re-excised and the PCR-DGGE process was repeated until all the samples showed a single DGGE band. The resulting PCR products were purified with the MEGAquickspin Total Kit (iNtRON Biotechnology Inc., Korea) for DNA sequencing. The purified DNAs were outsourced to the Genewiz Inc. (Genewiz Inc., South Plainfield, NJ), and each sample was sequenced separately with forward and reverse primers.

\subsection{Data analysis}

The DGGE image was analyzed by PyElph software (version 1.4) to examine DGGE bands profiles and to construct a phylogenetic tree using the unweighted pair group method with arithmetic mean (UPGMA) algorithm. The DNA sequences were analyzed using the Chromas Lite (version 2.1.1) to assess their quality. In order to confirm queries identity, the basic local alignment search tool algorithim (BLAST) was used to search homologus sequences in the 
GenBank DNA libraries.

\section{Results and Discussion}

\subsection{Corexit 9500A and crude oil effects on the bacterial community structure}

The structure of the bacterial community in the salt marsh sediments was significantly shifted after 60 days exposure to Corexit 9500A, crude oil, and Corexit 9500A plus crude oil. The DGGE band patterns, numbers, and intensities in the treated microcosms were shifted (figure 1A). The bacterial diversities in the treated microcosms were reduced, and the abundance of some bacterial species was increased, which was represented by the intense bands in each treatment. PyElph analysis showed that the control and crude oil treatments were phylogenetically close and occupied the first cluster of the tree. The second cluster included Corexit 9500A and Corexit 9500A plus crude oil treatments (Figure 1B).

\subsection{Phylogenetic analysis of the main DGGE bands}

The main DGGE bands in Corexit 9500A treatment were B1, B2, and B3 (figure 1A). DNA sequence analysis of these bands suggested that they were phylogenetically close to Pandoraea thiooxydans strain ATSB16 ${ }^{\mathrm{T}}$, Janthinobacterium sp. T3-QB-2044, and Hyphomicrobium nitrativorans strain NL23 ${ }^{\mathrm{T}}$, respectively (Table 2). Pandoraea thiooxydans strain ATSB16T, a facultatively chemolithoautotrophic, sulfuroxidizing bacterium, was isolated from a rhizosphere soil of the sesame plant (Sesamum indicum L.) [16]. Pandoraea thiooxydans strains of environmental sources are involved in degradation of many environmental pollutants [17]. The strain ATSB $16^{\mathrm{T}}$ can grow chemolithoautotrophically with sulfur, sulfite, thiosulfate, and tetrathionate. Furthermore, this strain is capable of reducing nitrate and hydrolyzing Tween 80 for growth [16]. The bacterial genus Janthinobacterium includes several hydrocarbon-degrading strains, such as Janthinobacterium sp. J3 and Janthinobacterium sp. J4. Janthinobacterium sp. J3 possesses CAR-catabolic genes that are capable of metabolizing carbazole, an $\mathrm{N}$-hetedrocyclic aromatic compound has been extracted from crude oil, shale oil, and creosote [18]. Hyphomicrobium nitrativorans strain $\mathrm{NL}^{2} 3^{\mathrm{T}}$ was isolated from a biofilm of a methanol-fed denitrification system treating seawater, Canada [19]. The genome analysis of this strain has identified a number of ORFs encoding enzymes that are involved in nitrite, nitrate, nitric oxide, and nitrous oxide reduction. Corexit 9500A's hydrocarbons and Tween 80 , as well as the high concentrations of nitrate, nitrite, sulfur, and sulfate, might have enhanced the population of species Pandoraea thiooxydans, Janthinobacterium sp., and Hyphomicrobium nitrativorans to thrive in these contaminated conditions and dominate the bacterial community. The DGGE bands B4, B5, and B6 were the major bands in the crude oil treatment. DNA sequence analysis of these bands revealed that they were homologous to
Hydrocarboniphaga effusa strain AP103 ${ }^{\mathrm{T}}$, Parvibaculum lavamentivorans strain DS- $1^{\mathrm{T}}$ and Alicyclobacillus ferrooxydans isolate YE3-D4-31i-CH, respectively (table 2). Hydrocarboniphaga effusa strain $\mathrm{AP} 103^{\mathrm{T}}$ is a hydrocarbon degrading bacterium, and it has been isolated from crude oil contaminated environments. This strain degrades particularly $\mathrm{n}$-alkanes forms of hydrocarbons, and the genomic analysis of this strain has confirmed presence two genes encoding alkane omega monooxygenase enzymes (Alk-like enzymes) involving in alkanes degradation [20]. Parvibaculum lavamentivorans strain $\mathrm{DS}-\mathrm{1}^{\mathrm{T}}$ has an ability to completely degrade linear alkylbenzenesulfonate (LAS) surfactants [21], and it is considered a typical member of many heterotrophic LASdegrading bacteria [22].

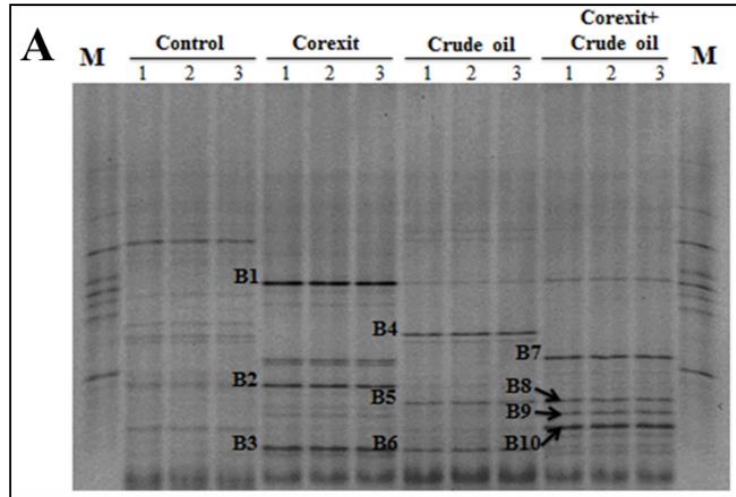

B

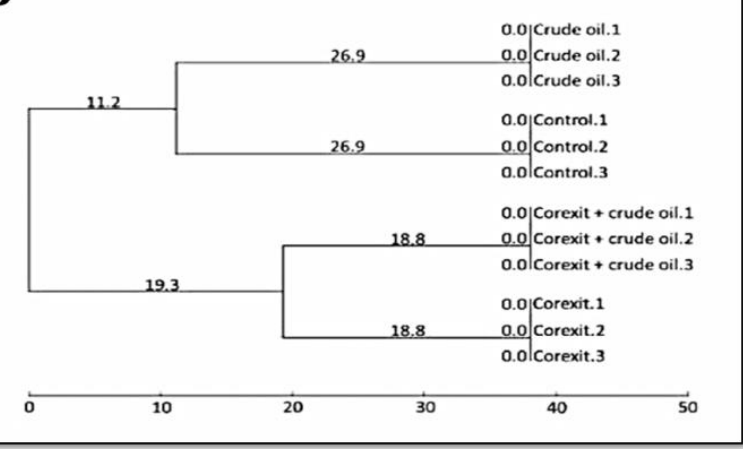

Figure 1: Bacterial community shift after 60 days of exposure to Corexit 9500A, crude oil, and Corexit 9500A plus crude oil. (A) DGGE profiles of bacterial 16s rRNA gene in sediment microcosms treated with $0.2 \%$ of Corexit $9500 \mathrm{~A}, 2 \%$ of crude oil, and $0.2 \%$ of Corexit 9500 A plus $2 \%$ of crude oil. (B) Unweighted Pair Group Method with Arithmetic Mean (UPGMA) dendrogram of DGGE profiles. The values on the horizontal lines stand for genetic distances among treatments in percentages. M: marker; numbers 1,2 , and 3 represent individual triplicate

Table 2: Phylogenetic affiliation between the isolated DGGE bands and their close relative organisms with the GenBank accession numbers and percentages identity

\begin{tabular}{|c|c|c|c|}
\hline Band & Close relatives in GenBank databases & GenBank Accession no. & $\begin{array}{l}\text { Percent } \\
\text { identity }\end{array}$ \\
\hline $\mathrm{B} 1$ & Pandoraea thiooxydans strain ATSB16 ${ }^{\mathrm{T}}$ & NR_116008 & 99.37 \\
\hline B2 & Janthinobacterium sp. T3-QB-2044 & KJ9̄22698 & 96.42 \\
\hline B3 & Hyphomicrobium nitrativorans strain $\mathrm{NL}^{2} 3^{\mathrm{T}}$ & NR_121713 & 90.43 \\
\hline B4 & Hydrocarboniphaga effusa strain AP103 ${ }^{\mathrm{T}}$ & NR_029102 & 86.71 \\
\hline B5 & Parvibaculum lavamentivorans strain DS- $1^{\mathrm{T}}$ & NR_074262 & 91.77 \\
\hline B6 & Alicyclobacillus ferrooxydans isolate YE3-D4-31i-CH & FN8̄70342 & 85.71 \\
\hline B7 & Janthinobacterium sp. A1-13 & AB252072 & 84.28 \\
\hline B8 & Parvibaculum lavamentivorans strain DS $1^{\mathrm{T}}$ & NR_074262 & 93.08 \\
\hline B9 & Parvibaculum lavamentivorans strain DS-1 ${ }^{\mathrm{T}}$ & NR_074262 & 98.78 \\
\hline $\mathrm{B} 10$ & Dyella sp. sk100104 & GU5552467 & 93.71 \\
\hline
\end{tabular}


The genus Parvibaculum includes several hydrocarbondegrading species, which have been isolated from hydrocarbon contaminated environments $[23,24]$. Crude oil addition and biosurfactants produced by bacterial degradation of hydrocarbons might have enhanced this bacterial strain to dominate the bacterial community in crude oil treated microcosms. Alicyclobacillus ferrooxydans has the ability to metabolize various carbon forms as sources for growth and energy. This species can also grow by oxidation of ferrous iron, sulfides, and elemental sulfur [25]. Chemical analysis showed that the salt marsh sediment sample has a high concentration of iron, sulfate, and sulfur (Table 1).

The major DGGE bands in Corexit 9500A plus crude oil treatment were B7, B8, B9, and B10 (table 2). DNA sequence analysis revealed that $\mathrm{B} 7$ was phylogenetically homologous to Janthinobacterium sp. A1-13. Janthinobacterium sp. A1-13, an acid tolerant bacterium, was isolated from peat soil in Indonesia [26]. This bacterium inhabits heavily contaminated industrial wastes [27], and it is considered one of the most important $\mathrm{N}_{2} \mathrm{O}$-producing bacteria in such environments [26]. The bands B8 and B9 were homologous to Parvibaculum lavamentivorans strain DS $1^{\mathrm{T}}$. Parvibaculum lavamentivorans strain DS- $1^{\mathrm{T}}$ has the ability to completely degrade linear alkylbenzenesulfonate (LAS), a major laundry surfactant [21]. Corexit 9500A surfactants might have enriched this strain under these conditions. The band B10 was homologous to Dyella sp. sk100104. This strain was isolated from a contaminated forest soil with a mixture of xenobiotics, including 1-amino-2-propanol (APOL), 1 methyl-2pyrrolidinone (MP), 1- dioxide (THT), diethylene glycol monoethyl ether (DGMEE), diethylene glycol monomethyl ether (DGMME), tetraethylene glycol (TEG), and tetramethylammonium hydroxide (TMAH), and this bacterium ability to degrade these contaminants has been reported [28]. The majority of these compounds are glycol-based solvents, which are similar to Corexit 9500A constituents.

\section{Conclusion}

The structure of the bacterial community in the salt marsh sediments was significantly shifted in response to Corexit9500A plus crude oil treatment, and it was different from those either Corexit 9500A or crude oil treatment. Corexit 9500A addition to crude oil showed combined effects on the bacterial community and enhanced the biodegradation rate by way of increasing the diversity and richness of hydrocarbons degrading species. Further studies are required to determine the long-term combined effects of Corexit 9500A plus crude oil on the environment to evaluate the environmental impacts of dispersants application during oil spills.

\section{Acknowledgement}

I am grateful for the Higher Committee for Education Development in Iraq (HCED) and Troy University, Troy, AL. USA/ the Faculty Development Research grants, for funding this research.

\section{Ethical issue}

Author is aware of, and comply with, best practice in publication ethics specifically with regard to authorship (avoidance of guest authorship), dual submission, manipulation of figures, competing interests and compliance with policies on research ethics. Authors adhere to publication requirements that submitted work is original and has not been published elsewhere in any language.

\section{Competing interest}

The author declares that there is no conflict of interest that would prejudice the impartiality of this scientific work.

\section{References}

1. Prince R, Atlas RM. Bioremediation of marine oil spills. Bioremediation: Applied microbial solutions for real-world environmental cleanup. Oil \& Gas Science and Technology. 2003 Apr 29:269-92.

2. Brakstad OG, Nordtug T, Throne-Holst M. Biodegradation of dispersed Macondo oil in seawater at low temperature and different oil droplet sizes. Marine Pollution Bulletin. 2015 Apr 15;93(12):144-52.

3. Singer MM, George S, Lee I, Jacobson S, Weetman LL, Blondina G, Tjeerdema RS, Aurand D, Sowby ML. Effects of dispersant treatment on the acute aquatic toxicity of petroleum hydrocarbons. Archives of Environmental Contamination and Toxicology. 1998 Feb 1;34(2):177-87.

4. Zahed MA, Aziz HA, Isa MH, Mohajeri L. Effect of initial oil concentration and dispersant on crude oil biodegradation in contaminated seawater. Bulletin of Environmental Contamination and Toxicology. 2010 Apr 1;84(4):438-42.

5. Haritash AK, Kaushik CP. Biodegradation aspects of polycyclic aromatic hydrocarbons (PAHs): a review. Journal of Hazardous Materials. 2009 Sep 30;169(1-3):1-5.

6. Alabresm A, Chen YP, Decho AW, Lead J. A novel method for the synergistic remediation of oil-water mixtures using nanoparticles and oil-degrading bacteria. Science of the Total Environment. 2018 Jul 15;630:1292-7.

7. Ramachandran SD, Hodson PV, Khan CW, Lee K. Oil dispersant increases PAH uptake by fish exposed to crude oil. Ecotoxicology and Environmental Safety. 2004 Nov 1;59(3):300-8.

8. Fiocco RJ, Lewis A. Oil spill dispersants. Pure and Applied Chemistry. 1999 Jan 1;71(1):27-42.

9. Atlas RM, Hazen TC. Oil biodegradation and bioremediation: a tale of the two worst spills in US history. Environmental Science and Technology. 2011;45:6709-15.

10. Prince RC, Butler JD. A protocol for assessing the effectiveness of oil spill dispersants in stimulating the biodegradation of oil. Environmental Science and Pollution Research. 2014 Aug 1;21(16):9506-10.

11. Techtmann SM, Zhuang M, Campo P, Holder E, Elk M, Hazen TC, Conmy R, Santo Domingo JW. Corexit 9500 enhances oil biodegradation and changes active bacterial community structure of oil-enriched microcosms. Applied and Environmental Microbiology. 2017 May 15;83(10). e03462-16.

12. Swannell RP, Daniel F, Croft BC, Engelhardt MA, Wilson S, Mitchell DJ, Lunel T. Influence of physical and chemical dispersion on the biodegradation of oil under simulated marine conditions. In Arctic and marine oil spill program technical seminar. 1997 Jun (Vol. 1, pp. 617-642). Ministry of supply and Services, Canada.

13. Bælum J, Borglin S, Chakraborty R, Fortney JL, Lamendella R, Mason OU, Auer M, Zemla M, Bill M, Conrad ME, Malfatti SA. Deep-sea bacteria enriched by oil and dispersant from the Deepwater Horizon spill. Environmental Microbiology. 2012 Sep;14(9):2405-16.

14. Al-Jawasim M, Yu K, Park JW. Synergistic effect of crude oil plus dispersant on bacterial community in a Louisiana salt marsh sediment. FEMS Microbiology Letters. 2015 Sep 1;362(17).

15. Muyzer G, De Waal EC, Uitterlinden AG. Profiling of complex microbial populations by denaturing gradient gel electrophoresis analysis of polymerase chain reaction-amplified genes coding for 16S rRNA. Applied and Environmental Microbiology. 1993 Mar 1;59(3):695-700.

16. Anandham R, Indiragandhi $\mathrm{P}$, Kwon SW, Sa TM, Jeon CO, Kim YK, Jee HJ. Pandoraea thiooxydans sp. nov., a facultatively chemolithotrophic, thiosulfate-oxidizing bacterium isolated from rhizosphere soils of sesame (Sesamum indicum L.). International Journal of Systematic and Evolutionary Microbiology. 2010 Jan $1 ; 60(1): 21-6$.

17. Jiang XW, Liu H, Xu Y, Wang SJ, Leak DJ, Zhou NY. Genetic and biochemical analyses of chlorobenzene degradation gene 
clusters in Pandoraea sp. strain MCB032. Archives of Microbiology. 2009 Jun 1;191(6):485-92.

18. Inoue $\mathrm{K}$, Widada $\mathrm{J}$, Nakai $\mathrm{S}$, Endoh $\mathrm{T}$, Urata $\mathrm{M}$, Ashikawa $\mathrm{Y}$, Shintani M, Saiki Y, Yoshida T, Habe H, Omori T. Divergent structures of carbazole degradative car operons isolated from Gram-negative bacteria. Bioscience, Biotechnology, and Biochemistry. 2004 Jan 1;68(7):1467-80.

19. Martineau C, Villeneuve C, Mauffrey F, Villemur R. Complete genome sequence of Hyphomicrobium nitrativorans strain NL23 ${ }^{\mathrm{T}}$, a denitrifying bacterium isolated from biofilm of a methanol-fed denitrification system treating seawater at the Montreal Biodome. Genome Announcements. 2014 Feb 27;2(1). 2:e01165-13.

20. Chang HK, Zylstra GJ, Chae JC. Genome Sequence of n-AlkaneDegrading Hydrocarboniphaga effusa Strain AP103 ${ }^{\mathrm{T}}$ (ATCC BAA-332 ). Journal of Bacteriology. 2012; 194:5120-25.

21. Schleheck D, Knepper TP, Eichhorn P, Cook AM. Parvibaculum lavamentivorans DS $-1^{\mathrm{T}}$ degrades centrally substituted congeners of commercial linear alkylbenzenesulfonate to sulfophenyl carboxylates and sulfophenyl dicarboxylates. Applied and Environmental Microbiology. 2007 Aug 1;73(15):4725-32.

22. Dong W, Eichhorn P, Radajewski S, Schleheck D, Denger K, Knepper TP, Murrell JC, Cook AM. Parvibaculum lavamentivorans converts linear alkylbenzenesulphonate surfactant to sulphophenylcarboxylates, $\alpha, \quad \beta$-unsaturated sulphophenylcarboxylates and sulphophenyldicarboxylates, which are degraded in communities. Journal of Applied Microbiology. 2004 Mar;96(3):630-40.

23. Alonso-Gutiérrez J, Figueras A, Albaigés J, Jiménez N, Vinas M, Solanas AM, Novoa B. Bacterial communities from shoreline environments (Costa da Morte, Northwestern Spain) affected by the Prestige oil spill. Applied and Environmental Microbiology. 2009 Jun 1;75(11):3407-18.

24. Wang L, Wang W, Lai Q, Shao Z. Gene diversity of CYP153A and AlkB alkane hydroxylases in oil-degrading bacteria isolated from the Atlantic Ocean. Environmental Microbiology. 2010 May;12(5):1230-42.

25. Jiang CY, Liu Y, Liu YY, You XY, Guo X, Liu SJ. Alicyclobacillus ferrooxydans sp. nov., a ferrous-oxidizing bacterium from solfataric soil. International Journal of Systematic and Evolutionary Microbiology. 2008 Dec 1;58(12):2898-903.

26. Hashidoko Y, Takakai F, Toma Y, Darung U, Melling L, Tahara $\mathrm{S}$, Hatano R. Emergence and behaviors of acid-tolerant Janthinobacterium $\mathrm{sp}$. that evolves $\mathrm{N} 2 \mathrm{O}$ from deforested tropical peatland. Soil Biology and Biochemistry. 2008 Jan 1;40(1):11625.

27. Maukonen J, Saarela M. Microbial communities in industrial environment. Current Opinion in Microbiology. 2009 Jun $1 ; 12(3): 238-43$.

28. Jeon BY, Park DH. Isolation of xenobiotic-degrading bacteria and analysis of bacterial community variation in soil microcosm contaminated with xenobiotics. Journal of the Korean Society for Environmental Analysis. 2010;13(2):85-91. 